\title{
THE FÉDÉRATION EQUESTRE INTERNATIONALE SPEAKS FOR THE HORSE WHO HAS NO VOICE AND THE COURT OF ARBITRATION FOR SPORT LISTENED: EQUINE WELFARE AND ANTI-DOPING IN EQUESTRIANISM
}

\author{
Dr Laura Donnellan*
}

\section{INTRODUCTION}

The strict liability standard employed by the Fédération Equestre Internationale (FEI) in equine doping cases has been a source of contention among academics, riders and trainers. The FEI Disciplinary Tribunal and the Court of Arbitration for Sport (CAS) have consistently upheld the standard and no alternative has been considered. At the core of the application of the strict liability standard has been the protection of the equine athlete. With the dual aims of the protection of equine athletes and equality between competitors, the FEI imposes a provisional equine suspension when a horse's sample records an adverse analytical finding. The standard of strict liability and the imposition of provisional suspensions together put the welfare of the horse to the fore. While the intentions of the FEI have been based on this noble premise, ambiguities and inconsistencies have undermined the effectiveness of the Equine Anti-Doping and Controlled Medication Regulations (EADCMRs).

The aim of this article is to examine whether the regulatory framework, the EADCMRs, is fit for purpose and adequately protects the equine athlete. The article will focus on two main principles that underpin the EADCMRs, namely provisional equine suspensions and the standard of strict liability. Recourse will be made to seminal cases that will act as a lens through which the regulatory framework can be assessed. A recent case involving American dressage competitors and the imposition of provisional equine suspensions highlighted the need for the FEI to make more explicit the basis on which the rule was created. The CAS upheld the FEI's policy of provisionally suspending horses for two-months on grounds of animal welfare and ensuring a level playing field. However, the CAS agreed with the appellants as to the lack of clarity surrounding

\footnotetext{
Lecturer in Law, School of Law, University of Limerick, Ireland.
} 
the provisional suspension. In examining the application of the principle of strict liability, the article will determine whether it is an appropriate standard and whether a relaxation of the standard is feasible or if it would compromise the welfare of the horse.

In order to put the regulatory framework into context, the article will discuss the purpose of anti-doping, the history of doping and equine sports and the ethical issues that equine doping invokes. It will trace the development of the EADCMRs against the background of positive tests at the 2004 Olympic Games in Athens and the 2008 Olympic Games in Beijing. Following the subsequent appeal of FEI Tribunal decisions to the CAS, all of which the CAS upheld, the FEI set about establishing a more robust regulatory framework. While the current regulations are comprehensive, their verboseness has led to confusion, testament to this is the number of appeals of FEI Tribunal decisions to the CAS.

\section{THE PURPOSE OF DOPING IN EQUINE SPORT: EQUINE WELFARE}

The relationship between humans and horses can be traced back thousands of years. While it is unclear why horses were first domesticated, it is surmised that they were first used for the purposes of meat and subsequently as 'tools' for transportation. ${ }^{1}$ Horses played an important role in World War I and World War II; however, after World War II, working horses all but disappeared. ${ }^{2}$ Increased mechanisation and the ensuing increase in leisure time changed the role and indeed perception of the horse from a tool of transportation or a source of food to a 'leisure animal'. ${ }^{3}$ Horses first competed in the Olympic Games in Stockholm in 1912. Today, there are only three Olympic sports where human and equine athletes compete together: jumping, eventing and dressage. ${ }^{4}$ The pivotal role of the

\footnotetext{
1 Martine Hausberger, Helene Roche, Severine Henry and Kathalijne Visser, 'A Review of the Human-Horse Relationship' (2008) 109 Applied Animal Behaviour Science 1, 2.

2 MA Atock and RB Williams, 'Welfare of Competition Horses' (1994) 13(1) Revue Scientifique et Technique de l'OIE 217, $23<$ https://pdfs.semanticscholar. org/2084/76b91c06991d8272747d215a7fc67cb630b3.pdf> accessed 7 April 2019.

3 Ibid. Hausberger et al. (n 2) 3 refer to the 'mixed status' of the horse, a 'source of food for some, for leisure and sport for others, or, less frequently, an agricultural working companion in rural areas'. See also Michelle Gilbert and James Gillett, 'Equine Athletes and Interspecies Sport' (2011) 47(5) International Review for the Sociology of Sport 632. The writers refer to the limited use of horses in modern society as horses are primarily used for leisure and recreation.

${ }^{4}$ Kent Allen and Stephen A Schumacher, 'Impact of the FEI Rules on Sport Horse
} 
regulatory bodies of horse sports is the safeguarding of the welfare of the horse. The welfare of horses 'must always be the primary driving force', even in situations when it conflicts with 'certain commercial aspects of the industry'. ${ }^{5}$ The Fédération Equestre Internationale (FEI), the world governing body for equestrian sports, in safeguarding the welfare of horses, has a Code of Conduct for the Welfare of the Horse. ${ }^{6}$ The Code enumerates a number of requirements that human agents must uphold including general equine welfare considerations, for example good horse management, training methods, farriery and tack, transport and transit. ${ }^{7}$ Under fitness to compete, there are guidelines on fitness and competence, health status and doping and medication. Under the EADCMRs, it states:

Any action or intent of doping and illicit use of medication constitute a serious welfare issue and will not be tolerated. After any veterinary treatment, sufficient time must be allowed for full recovery before Competition. ${ }^{8}$

All those involved in international equestrianism are bound by the Code, which states that 'at all times the welfare of the horse must be paramount'.

It is clear from these sections of the Code that the FEI operates in a custodian type role, as a representative for the equine athlete. ${ }^{10}$ Equestrianism presents a unique bond between the human and the animal. ${ }^{11}$ The CAS recognised this imitable relationship, in particular the vulnerable position of the horse as it contended that ' $[\mathrm{h}]$ orses, unlike humans, cannot themselves take care to avoid the

Medications' in Kim A Sprayberry and N Edward Robinson (eds), Robinson's Current Therapy in Equine Medicine (7 $7^{\text {th }}$ ed, Elsevier Health Sciences 2014) 112. The first time horses participated in the Ancient Olympics dates back to 680 BC, FEI, 'History' <http:// history.fei.org/node/104> accessed 7 April 2019.

5 Ibid.

${ }^{6}$ FEI, 'FEI Code of Conduct for the Welfare of the Horse' (FEI), 2013, <https://inside.fei. org/system/files/Code_of_Conduct_Welfare_Horse_1Jan2013.pdf> accessed 7 April 2019.

${ }^{7}$ Ibid.

8 Ibid.

9 Ibid., 1

${ }^{10}$ FEI, 'Our Values' (FEI), 2019, <https://inside.fei.org/fei/about-fei/values-history> accessed 28 March 2019.

${ }^{11}$ Ibid. It is a not-for-profit organisation which aims to 'drive and develop equestrian globally in a sustainable, progressive and structured manner whilst ensuring maximum visibility and promotion of our seven unique disciplines'. 


\section{THE FÉDÉRATION EQUESTRE INTERNATIONALE SPEAKS FOR THE HORSE WHO HAS NO VOICE AND THE COURT OF ARBITRATION}

ingestion of prohibited substances. The welfare and health argument has a proper and particular resonance in their case'. ${ }^{12}$

\section{The History of Doping and Horses}

While human doping can be traced back to Ancient Greece, there is no indication that horses were doped; however, according to Greek mythology, King Diomedes of Thrace gave horses human flesh to consume to 'make them savage and unbeatable'. ${ }^{13}$ It is reasonable to contend that horses would have been given dietary supplements in the Ancient Olympics. ${ }^{14}$ Horses in Ancient Roman times, it is claimed, were given a mixture of honey and water to increase endurance. ${ }^{15}$ Higgins concludes that '[1]ittle is known of the evolution of horse doping over the following sesquimillenium.'. 16

Doping of horses was first prohibited in horseracing. The Jockey Club in October 1903 announced that 'the practice known as doping' would result in the warning off from the turf. ${ }^{17}$ The rule provided that 'if any person or persons shall be proved to have administered, for the purpose of affecting the speed of a horse, drugs or stimulants internally, by hypodermic or other methods', the persons involved would receive a warning off. Up until this point, doping was permitted and it would seem that the Jockey Club did nothing to dissuade it. The introduction of the rule was stated to be based on concerns for the welfare of horses. However, there was anecdotal evidence from Russia and Austria that doping impaired breeding; the French Jockey Club had decided to prohibit it at around the same time as the English Jockey Club. ${ }^{18}$ Doping was used to both improve and slow down horses and the prohibition on the use of drugs was very much tied up with fairness and betting and had nothing to do with 'the typically assumed twentieth

12 Arbitration CAS 2017/A/5114 Elizabeth Juliano, Owner of Horizon; Maryanna Haymon, Owner of Don Principe; Adrienne Lyle and Kaitlin Blythe v Fédération Equestre Internationale (FEI), award of 19 March 2018, para 68, <http://jurisprudence.tas-cas.org/ Shared\%20Documents/5114.pdf>

13 AJ Higgins, 'From Ancient Greece to Modern Athens: 3000 Years of Doping in Competition Horses' (2006) 29(1) Journal of Veterinary Pharmacology and Therapeutics 4, 6 .

14 Ibid.

15 Ibid.

16 Ibid.

17 Editorial, 'The Newmarket and Kempton Meetings' (Times, 6 October 1903) 2.

18 Ibid. 
century concerns about safety or preserving the spirit of sport'. ${ }^{19}$ The anti-doping attitude that prevailed at the time signified the modernisation of horseracing, as it was the first sport to identify and prohibit doping. ${ }^{20}$

By 1910, it was possible to test for the presence of alkaloids in the saliva of horses. ${ }^{21}$ Saliva testing for alkaloids including caffeine, cocaine, morphine and strychnine were being conducted in most racing countries by $1913 .^{22}$ As the sanction for a positive test was disqualification, there was a decline, albeit a brief one, in incidences of doping. The legalisation of pari-mutuel betting in the United States in 1933 resulted in an increase in doping. ${ }^{23}$ During the 1930s, it was claimed that fifty per cent of all racehorses were doped. ${ }^{24}$ The purpose of doping racehorses was for one of two purposes, to make the horse go faster or cause the horse to go slower. ${ }^{25}$ Stimulants such as strychnine and caffeine would be used to make the horse go faster and to the slow down the horse, s/he would be given a large dose of barbiturates or chloral. ${ }^{26}$ More indirect methods would also be used, for example, a horse who was suffering from lameness after surgery would be given an injection or a local anaesthetic applied to the affected area and thus mask the pain and treat the lameness. ${ }^{27}$ Tranquilisers would also be given to 'obstreperous' horses to make them more manageable. ${ }^{28}$ The administration of prohibited substances or methods was not only a breach of the rules of racing; it also caused horses to compete while injured and exacerbate the injury. It was contended that fifty per cent of US racehorses had been given a stimulate or a local anaesthetic before a race resulting in a "much higher incidence of injuries during races caused by insensitivity to pain and lack of proper coordination of muscular movement owing to the administration of massive doses of cocaine, heroin, strychnine and caffeine'. ${ }^{29}$ A concern for racing authorities was that doping would

19 John Gleaves, 'Enhancing the Odds: Horseracing, Gambling and First Anti-Doping Movement in Sport, 1889-1911' (2012) 32(1) Sport in History 26, 27.

20 Ibid., 28-29.

${ }^{21}$ Michele Verroken, 'Drug Use and Abuse in Sport' in David Mottram (ed), Drugs in Sport ( $2^{\text {nd }}$ edn, E \& FN Spon 1996) 19. It was found that saliva was the most reliable to test in comparison to sweat, faeces and urine, Higgins (n 14) 6.

22 Ibid.

23 Ibid.

24 EGC Clarke, 'The Doping of Racehorses' (1962) 30(4) Medico Legal Journal 180, 184.

25 Ibid., 181.

26 Ibid.

27 Ibid.

28 Ibid.

29 LF Addis-Smith, 'The Changing Pattern of "Doping" in Horse Racing and Its Control' (1961) 9(6) New Zealand Veterinary Journal 121. 


\section{THE FÉDÉRATION EQUESTRE INTERNATIONALE SPEAKS FOR THE HORSE WHO HAS NO VOICE AND THE COURT OF ARBITRATION}

result in a dilution of the quality of the thoroughbred racehorse as some 'breeders complained of impotency, sterility and weak foals. ${ }^{30}$ The 'yardstick' used in racing is that of the performance record of the horse, thus ' $[\mathrm{a}]$ horse must win on its merits, or the whole system of selection for breeding purposes becomes meaningless'. ${ }^{31}$ The welfare of the horse and the ethical issues that surround doping did not feature in the literature from this time.

While horseracing had been the forerunner when it came to anti-doping, the FEI was initially of the view that equestrian sports were 'relatively clean'. ${ }^{32}$ Situations where horses tested positive, were for the most part, the result of antiinflammatory administered by the person responsible or the veterinary surgeon, which had been given too close to the time of competition. ${ }^{33}$ The 'dividing line' between a horse receiving medical treatment to be restored to 'pre-wear and tear level' and a horse being prepared for competition became increasingly blurred. ${ }^{34}$

\section{The Ethical Issues}

The use of drugs in equine sports raises several ethical issues. The Animal Welfare Act 2006 refers to 'unnecessary harm'; it is difficult to apply 'unnecessary harm' to equine sports as the use of horses in sport is not 'strictly necessary'. ${ }^{35}$ The more appropriate term is 'avoidable suffering', as this term arguably enables humans 'to address the welfare issues associated with sporting use of animals even if one believes ... that the use of animals for sport is fundamentally unethical'. ${ }^{36}$

There are two important considerations when it comes to doping and horses. If a horse is being doped in order to enhance performance, there is an element of cheating, which is against the principles of clean and fair competition. There is also an animal welfare issue if a substance is given to a horse either to enhance performance or to mask an injury. ${ }^{37}$ There is a grey area, that of contaminated food and supplements which can easily be ingested by the horse and unwittingly

\footnotetext{
30 Higgins (n 14) 6.

31 Addis-Smith (n 30).

32 Higgins (n 14) 6.

33 Ibid. The withdrawal time was insufficient and the horse would test positive.

34 Ibid.

35 MLH Campbell, 'When Does Use Become Abuse in Equestrian Sport?' (2013) 25(10) Equine Veterinary Education 489, 490. Section 4 of the Animal Welfare Act 2006 c.45 defines unnecessary harm, see <https://www.legislation.gov.uk/ukpga/2006/45/pdfs/ ukpga_20060045_en.pdf>

36 Ibid.

37 In the latter situation, the horse should not compete until the injury has fully healed.
} 
result in a positive test for a banned or controlled substance, as the case of Lyle and Blythe discussed below demonstrates. ${ }^{38}$ There is a moral and ethical dimension when it comes to administrating pharmacological products to equine athletes. ${ }^{39}$ However, the FEI distinguishes between doping (performance enhancing or masking an injury) and the use of bona fide veterinary treatment in the form of medication..$^{40}$ When it comes to taking a prohibited substance, the human athlete, in most cases, does so aware of the dangers and consequences, however, for the equine athlete, they have no choice in the matter. It is up to the FEI to speak for the equine athlete and safeguard his/her welfare.

\section{THE OLYMPIC GAMES OF 2004 AND 2008: A TURNING POINT}

The FEI is the international governing body for 134 affiliated national federations. ${ }^{41}$ It is the only international governing body for equestrian recognised by the International Olympic Committee (IOC). In 1921, France, Norway, Sweden, Belgium, Italy, Denmark, the United States and Japan founded the FEI in Lausanne, Switzerland. ${ }^{42}$ While it is not clear when the FEI introduced equine anti-doping provisions, in 1977 at an International Conference in Rome, representatives from the FEI and other horse sport bodies approved a list of prohibited substances. ${ }^{43}$

Although horseracing is not regulated by the FEI, the FEI has closely followed the anti-doping procedures of the regulatory bodies of horseracing. ${ }^{44}$ In the United

38 Decision of the FEI Tribunal 18 December 2018, Positive Anti-Doping Case No.: 2017/ BS16 Kaitlin Blythe <https://inside.fei.org/system/files/Case\%202017\%20-\%20BS16\%20 -\%20DON\%20PRINCIPE\%20-\%20FEI\%20Tribunal\%20Decision\%20-\%2018\%20 December\%202018\%20Rev.pdf> and Decision of the FEI Tribunal 18 December 2018, Positive Anti-Doping Case No.: 2017/BS15 Adrienne Lyle https://inside.fei.org/system/ files/Case \%202017\%20-\%20BS15\%20-\%20HORIZON\%20-\%20FEI\%20Tribunal\%20 Decision\%20-\%2018\%20December\%202018.pdf> accessed 21 August 2019.

39 Higgins (n 14) 4.

40 Ibid.

41 FEI, 'National Federations' (FEI) <https://inside.fei.org/fei/about-fei/structure/ national-federations $>$ accessed 7 April 2019. Its disciplines are vaulting, reining, driving and para, dressage and para, jumping, endurance and eventing.

42 Allen and Schumacher (n 5) 112.

43 Atock and Williams (n 3) 223.

44 Campbell (n 36) 490 notes that the anti-ulcer drug, omeprazole is permitted by the FEI, however, the British Horseracing Authority (BHA) prohibits it in competition but allows it to be used during training. He raises an interesting argument in regard avoidable harm in both banning and permitting omeprazole. If a horse is suffering from ulcers due to stress, 


\section{THE FÉDÉRATION EQUESTRE INTERNATIONALE SPEAKS FOR THE HORSE WHO HAS NO VOICE AND THE COURT OF ARBITRATION}

States, horseracing authorities have used the trainer 'absolute insurer rule', which places responsibility on the trainer to ensure that the horse does not ingest a prohibited substance..$^{45}$ It is described as 'an administrative, as opposed to statutory, rule. ${ }^{46}$ It is a form of no fault liability that is placed on the trainer. However, recent changes in by the rules by the Kentucky Horse Racing Commission now allow for mitigating and aggravating factors following a case where a Franklin Circuit Court judged questioned the constitutionality of the rule which denies the trainer the right to due process. The Kentucky Court of Appeal reversed the decision of the lower court on the grounds that '[b]y limiting the amount of medications and drugs given to horses the Commission is protecting the health of horses and ensuring the integrity of racing itself. These are significant rational reasons to uphold the regulation as constitutional'. ${ }^{47}$ While Judge Wingate's decision was overruled, it has resulted in changes to the Commission's regulations. ${ }^{48}$

The 2004 Olympics in Athens was a turning point for the FEI and anti-doping. Four equine athletes tested positive for banned substances, including Ireland's Cian O'Connor's horse, Waterford Crystal. ${ }^{49}$ O'Connor received a three month ban and was fined 5,000 Swiss francs. ${ }^{50}$

then this raises questions as to the management of the horse. By using the drug to deal with management issue is a form of avoidable harm. On the other hand, if the horse is suffering from ulcers due to intensive management and international travel then s/he should be given the drug to ease pain and thus reduce avoidable suffering.

45 Ray Paulick, 'Kentucky Court of Appeals: Absolute Insurer Rule Is Constitutional; Kitten's Point Medication DQ Upheld' (Paulick Report, 21 December 2018) <https://www. paulickreport.com/news/ray-s-paddock/kentucky-court-of-appeals-absolute-insurer-rule-isconstitutional-kittens-point-medication-dq-upheld > accessed 2 August 2019.

46 Bennett Liebman, 'The Trainer Responsibility Rule in Horse Racing' (Fall 2007) 7(1) Virginia Sports and Entertainment Law Journal 1, 2.

47 Ky. Horse Racing Commission v Motion, NO. 2017-CA-001458-MR (Ky. Ct. App. Dec. 21, 2018) para. 13. Franklin Circuit Court Judge Wingate held that the Kentucky Horse Racing Commission had acted outside the scope of its authority, there was a lack of due process and a lack of scientific evidence to support the finding in relation to the banned substance; these three factors pointed to the Commission acting in a 'capricious and arbitrary manner', see paras 4 and 14 of the Court of Appeal judgement.

48 Natalie Voss, 'Kentucky Rules Committee Approves Changes to Absolute Insurer Requirement' (Paulick Report, 10 April 2018) <https://www.paulickreport.com/news/thebiz/kentucky-rules-committee-approves-changes-to-absolute-insurer-requirement $>$ accessed 3 August 2019.

49 Waterford Crystal tested positive for fluphenazine and zuclopenthixol, human medicines for the treatment of schizophrenia.

${ }^{50}$ Louise Parks, 'Three-Month Ban as O'Connor Loses Gold' (Irish Independent, 28 
At the Beijing Olympics in 2008, four horses tested positive for capsaicin, a component of topical ointments for horses and used in 'Deep Heat' which humans use for the treatment of aches and pains. ${ }^{51}$ Irish rider, Denis Lynch, contended that he had used Equi-Block for over a year on his horse, Lantinus. ${ }^{52} \mathrm{He}$ stated that he had used Equi-Block to keep Lantinus' back muscles warm. ${ }^{53}$ Although Lantinus had been tested a number of times, he never tested positive until the 2008 Games. ${ }^{54}$ The FEI Tribunal, in banning Lynch for three months, applied the strict liability principle, which was subsequently endorsed by the CAS in the Ahlmann decision. ${ }^{55}$ At the FEI Tribunal hearing, Ahlmann could not explain the presence of the prohibited substance. ${ }^{56}$ However, under the principle of strict liability, intent is irrelevant. The mere presence of a prohibited substance is all that is required. The FEI Tribunal acknowledged that the 'heavy' burden is 'impossible to discharge'. ${ }^{57}$ In citing the jurisprudence of the CAS, the FEI Tribunal asserted that if intent were to be proved, it would make the fight against doping 'practically impossible'. ${ }^{58}$ It emphasised the FEI's medication policy as having the dual aims of ensuring a level playing field and animal welfare. In particular, the equine athlete, unlike the human rider, is unable to verbalise his/her feelings and it is vital for the image and progress of the sport to ensure that the horse's welfare is

March 2005) <https://www.independent.ie/irish-news/threemonth-ban-as-oconnor-losesgold-25997017.html> accessed 6 April 2019.

51 John T Wendt, 'The Crisis of Doping in Equestrian Sport' (2009) 27(3) Entertainment and Sports Lawyer 10.

52 Ibid.

53 Lynch appealed the FEI Tribunal decision to the Court of Arbitration for Sport (CAS), the CAS held that it had no jurisdiction to hear the appeal. Arbitration CAS 2008/A/1655 Denis Lynch v Fédération Equestre Internationale (FEI), award of 6 March 2009.

54 Ibid.

55 CAS 2008/A/1700 Deutsche Reiterliche Vereinigung eV v FEI \& Christian Ahlmann CAS 2008/A/1710 Christian Ahlmann v FEI. For a detailed discussion of the case see, Mary Zoeller, 'Gray Area: Court of Arbitration for Sport Says Neigh to Reconsidering Strict Liability for Equestrian Sport' (2016) 23(2) Jeffrey S. Moorad Sports Law Journal 457.

56 Decision of the FEI Tribunal dated 22 October 2008, Positive Medication Case No: 2008/20, Christian Ahlmann, para 4.3 (14) <https://inside.fei.org/system/files/20\%20 -\%20COSTER\%20-\%20Tribunal\%20Decision\%20-\%2022\%20October\%202008.pdf> accessed 1 August 2019. Both Samples A and B were tested and both were positive for capsaicin.

57 Ibid., para 4.8 .3 (55).

58 Ibid., citing the case of CAS 95/141, C v FINA, 22 April 1996, in Digest of CAS Awards, I, § 13. 


\section{THE FÉDÉRATION EQUESTRE INTERNATIONALE SPEAKS FOR THE HORSE WHO HAS NO VOICE AND THE COURT OF ARBITRATION}

strictly maintained'. ${ }^{59}$ Public perception was thus identified as an important consideration. The FEI contended that the person responsible owes a higher duty of care at the Olympics given the reputational damage that an adverse analytical finding can have on the sport. ${ }^{60}$ The FEI Tribunal agreed as the 'PR is an experienced sportsman and the behaviour of anyone at the top of the sport and particularly the Olympic Games must be faultless since the eyes of the world focus on performances at such events' ${ }^{61}$ Ahlmann was deemed to be negligent and was unable to discharge the burden that he bore no fault or negligence.

The FEI Tribunal disagreed with the FEI that a substance could be both a prohibited substance and a controlled medication. It is one or the other but not both. The use of the word 'or' and not 'and' meant that capsaicin fell under controlled medication, the FEI had failed to discharge the burden that Ahlmann had committed an anti-doping violation. ${ }^{62}$ Veterinary evidence proffered that capsaicin in this case was not used for hypersensitising purposes and thus the FEI Tribunal held that it constituted a controlled medication..$^{63}$ The FEI Tribunal in taking into account mitigation and aggravating factors placed a four-month period of ineligibility on Ahlmann, fined him 2,000 Swiss francs and ordered him to pay 1,500 Swiss francs towards the legal costs. ${ }^{64}$

The German National Federation challenged the FEI Tribunal decision and appealed it to the CAS as provided for under Article 39 of the FEI Statute, on the ground that Ahlmann should be banned for a period of not less than eight-months as capsaicin was a prohibited substance and not a controlled medication. ${ }^{65}$ Ahlmann subsequently challenged the appealed decision on the grounds that a

59 FEI Tribunal (n 57) para 4.8 .3 (57).

60 Ibid., para $4.10(80)$.

61 Ibid., para $4.10(87)$.

62 FEI Tribunal (n 57) para. 4.8 .2 (42-53).

63 Ibid., para 4.8.2. (52).

64 Ibid., para 4.10 (89). The mitigating factors included the following: Ahlmann did not have a prior violation, he had assisted in the investigation, he was a well-respected competitor, he had suffered hardship in being precluded from competing and thus he missed a number of important events, para 10.9 (79). Another important consideration for the FEI Tribunal was that the substance was newly detectable and was used by riders as a form of legitimate therapeutic use, para 10.9 (88). The aggravating factors identified by the FEI Tribunal included: the failed test took place at the Olympics, animal welfare concerns, the negligence of the PR not to check that the product contained a banned substance, para 10.9 (86-87).

65 CAS (n 56) para 31. See FEI Statute $2019<$ https://inside.fei.org/sites/default/files/ FEI\%20Statutes_2019_CLEAN_0.pdf $>$ accessed 2 August 2019. 
period of suspension in excess of three months was 'contrary to law' ${ }^{66} \mathrm{He}$ further contended that the FEI Prohibited List did not explicitly define doping and in using the contra proferentem rule, any ambiguity should be read in favour of Ahlmann. ${ }^{67}$ In arguing that the FEI Prohibited list was esoteric, counsel for Ahlmann asserted:

It would grossly contravene the principles of justice to sanction Mr. Ahlmann based on arbitrary rules that can only be understood by a small group of insiders and that leave grey areas between medication and doping and between legal and illegal practises. Further, such grey areas have to be interpreted in favour of Mr. Ahlmann, meaning that in case of doubts (grey area) a practice must be considered legal. ${ }^{68}$

The CAS increased the period of ineligibility to eight-months as it found that capsaicin fell under the anti-doping rules and not controlled medication as held by the FEI Tribunal. This case highlighted the ambiguities in the anti-doping and controlled medications regulations as the FEI contended that a substance could be both a prohibited substance and a controlled medication while its own disciplinary tribunal found that it was a controlled medication and as such it was deemed to be a lower level violation of the regulations. In the aftermath of the Ahlmann decision and other Olympic failed tests, the FEI adopted a more aggressive, coherent and proactive approach to doping.

\section{THE DEVELOPMENT OF THE FEI EQUINE ANTI-DOPING AND CONTROLLED MEDICATION REGULATIONS (EADCMRs)}

Following the positive tests at the Beijing Olympics, the FEI convened the Clean Sport Commission, headed by Professor Arne Ljungqvist, the Vice-President of WADA and Chairperson of the IOC Medical Commission. ${ }^{69}$ The purpose of the

${ }^{66}$ Ibid., para 27. He argued that the appeal should be dismissed as the German National Federation had delayed in filing the appeal and it had no legitimate interest in appealing to the CAS, para 44. See paras 45-50, the CAS found that the German National Federation had filed the appeal in a timely manner. See paras 51-59, the CAS concluded that the German National Federation as a member of the FEI had standing to bring the appeal.

${ }^{67}$ Ibid., para 32. Ahlmann also proffered that the amount of the substance used was so low that it could not be said to have a therapeutic effect.

${ }^{68}$ Ibid.

${ }^{69}$ The Commission continued on the work of the 2004 Doping and Medication Policy Taskforce. The Commission on Anti-Doping and Medication consisted of fourteen members plus the Chair and was comprised of representatives from the FEI, IOC, the 


\section{THE FÉDÉRATION EQUESTRE INTERNATIONALE SPEAKS FOR THE HORSE WHO HAS NO VOICE AND THE COURT OF ARBITRATION}

Commission was 'to establish the best possible system to promote drug-free equine sport ${ }^{\prime} .{ }^{70}$ The Commission gave cognisance to the fact that there was much confusion surrounding prohibited substances. It recommended that the anti-doping provisions be divided into two categories, anti-doping and controlled medications. In 2009, the FEI set up the Stevens' Commission, an Ethics Panel, headed by a former London Metropolitan Police Commissioner, to look into allegations in relation to the German equestrian team and its officials at the 2008 Olympics. ${ }^{71}$ The terms of reference of the Stevens' Report were expanded 'to include a wider overview of equestrian sport to dovetail with work of the Ljungqvist Commission and provide the FEI with a complete spectrum of changes to be implemented in the fight against doping. ${ }^{72}$ The Stevens' and Ljungqvist Commissions were aligned to produce the Joint Commission Recommendations, which were accepted at the General Assembly in Copenhagen on 19 November 2009.73 While the FEI viewed the recommendations as 'revolutionary changes designed to transform the face of equestrian sport', Merritt opines that the recommendations were 'woefully parochial' and 'the chance to treat horse sport as something fundamentally different to human-only sport was missed' ${ }^{74}$ Merritt's appraisement in relation to developments in 2009 applies equally to the current EADCMRs. The fact that they are based on the WADA Code that applies to human athletes, little or no ingenuity was employed in creating a specific anti-doping code for equine athletes. This raises the question whether they are fit for purpose. The FEI's contention that the Joint Commission Recommendations heralded 'revolutionary changes' must be viewed from the perspective that they were better than what had gone before. As the Blythe and Lyle case demonstrates, there is ambiguity surrounding specified substances and the two-month suspension for equine athletes.

CAS, an owner representative, veterinarians and three equestrian athletes. The Commission was divided into four focus groups: Laboratory Working Group, Legal Working Group, List Working Group and Communications and Education Working Group, FEI, 'Clean Sport History' <https://inside.fei.org/system/files/Clean\%20Sport\%20 History.pdf $>$ accessed 8 April 2019.

70 Allen and Schumacher (n 5) 112.

71 Merritt is critical of the appointment of a former head of Scotland Yard "who, as a key part of the prosecution arm of the state, would be unlikely to have any problem with the concept of strict liability. His panel was also drawn from the equestrian ruling class', Jonathan G Merritt, Regulating Sport for the Non-Human Athlete: Horses for Courses (Rowman \& Littlefield 2018) 136.

72 FEI, 'Clean Sport History' (n 70).

73 Ibid.

74 Merritt (n 72) 131-132. 
In April 2010, the FEI announced its Clean Sport Initiative, which included the first Equine Prohibited Substances List (EPSL) and the Equine Anti-Doping and Controlled Medications (EADCM) Regulations. ${ }^{75}$ The EPSL, like the WADA list of prohibited substances, is reviewed annually; the most recent list was approved on 30 November 2018 and came into force on 1 January 2019.76

The FEI has a tab on its website called 'Clean Sport' which contains a number of documents in relation to its doping policy. ${ }^{77}$ For the human participants, the WADA Code applies. ${ }^{78}$ The Clean Sport for Horses includes the following documents: the FEI Equine Anti-Doping and Controlled Medication Regulations (the Regulations), ${ }^{79}$ Prohibited Substances (Equine Prohibited Substance List, EPSL),${ }^{80}$ Education, ${ }^{81}$ Veterinary Forms, ${ }^{82}$ How Testing Works ${ }^{83}$ and Testing Results and Positive Cases ${ }^{84}$ The EADCMRs are divided into two: the Equine Anti-Doping (EAD) Rules and the Equine Controlled Medication (ECM) Rules. ${ }^{85}$

75 Allen and Schumacher (n 5) 113.

76 FEI, '2019 Equine Prohibited Substances List' <https://inside.fei.org/sites/default/ files/2019\%20Prohibited\%20Substances\%20List_0.pdf $>$ accessed 8 April 2019.

77 FEI, 'Clean Sport: Horses' <http://inside.fei.org/fei/cleansport/horses> accessed 6 April 2019.

78 FEI, 'Clean Sport: Humans' <http://inside.fei.org/fei/cleansport/humans> accessed 7 April 2019. The rules relating to equine doping incorporate the principles of the WADA Code. The FEI Anti-Doping Rules for Human Athletes (ADRHA) are based on the WADA code and may be accessed at $<$ https://inside.fei.org/sites/default/files/FEI\%20 ADRHA\%20based $\% 20$ upon $\% 20$ the $\% 202015 \% 20$ WADA $\% 20$ Code $\% 2 C \% 20$ effective $\% 20$ 1\%20January\%202015_0.pdf> accessed 7 April 2019.

79 FEI, 'Clean Sport for Horses - Regulations' < http://inside.fei.org/fei/cleansport/horses/ regulations $>$ accessed 7 April 2019.

${ }^{80}$ FEI, 'Clean Sport for Horses - FEI Prohibited Substances List' <http://inside.fei.org/ fei/cleansport/ad-h/prohibited-list $>$ accessed 7 April 2019. The EPSL is reviewed on an annual basis.

81 FEI, 'Clean Sport for Horses - Education' <http://inside.fei.org/fei/cleansport/horses/ education $>$ accessed 20 August 2019.

82 FEI, 'Clean Sport for Horses - Veterinary Forms' < http://inside.fei.org/fei/cleansport/ ad-h/medforms $>$ accessed 20 August 2019.

83 FEI, 'Clean Sport for Horses - How Testing Works' < http://inside.fei.org/fei/cleansport/ ad-h/how-testing-works $>$ accessed 20 August 2019

84 FEI, 'Test Results \& FEI Tribunal' < http://inside.fei.org/fei/cleansport/horses/testingresults $>$ accessed 20 August 2019.

85 EADCMRs, $2^{\text {nd }}$ Edition effective 1 January 2019, $1<$ https://inside.fei.org/sites/default/ files/EADCMRs\%20-\%20Effective\%201\%20January\%202019\%20-\%20Final\%20 Version_Clean\%20-\%20For\%20Publication_0.pdf> accessed 5 April 2019. 


\section{THE FÉDÉRATION EQUESTRE INTERNATIONALE SPEAKS FOR THE HORSE WHO HAS NO VOICE AND THE COURT OF ARBITRATION}

The banned substances and controlled medication are collectively referred to as the Prohibited Substances. ${ }^{86}$

A number of concerns emerge from the CAS decision in Blythe and Lyle, namely the confusion surrounding the interpretation of the EADCMRs and the lack of a codified rule that sets out the two-month provisional equine suspensions. In addition, there is the dichotomous position of the horse being considered an 'equine athlete' on the one hand, according to the FEI in press releases, ${ }^{87}$ and on its Clean Sport webpage as the FEI explains that the EADCMRs 'exist to protect the health of our athletes - equine and human - as well as the integrity of our sport'. ${ }^{88}$ On the other hand, the EADCMRs do not refer to the equine athlete. However, the CAS has recognised the horse's status as an equine athlete:

[T] he central and distinctive feature of equestrian sport is that it involves a partnership between two types of athlete, one human and one equine. One of those partners is unable to speak for itself, and therefore the FEI has assumed responsibility for speaking on its behalf, by taking every necessary step to ensure that, in every aspect of the sport, the welfare of the horse is paramount. ${ }^{89}$

Further inconsistencies are evidenced by the fact the fact that the EADCMRs are a 'modified' version of the WADA Code, the anti-doping code for human

\footnotetext{
86 Banned substances are defined 'as substances that are deemed by the FEI to have no legitimate use in the competition horse and/or have a high potential for abuse. They are not permitted for use in the competition horse at any time'. Controlled Medications are defined 'as substances that are deemed by the FEI to have therapeutic value and/or be commonly used in equine medicine. Controlled Medications have the potential to affect performance and/or be a welfare risk to the horse', FEI, 'Clean Sport for Horses - FEI Prohibited Substances List' <http://inside.fei.org/fei/cleansport/ad-h/prohibited-list> accessed 21 August 2019.

87 The FEI's Secretary General Sabrina Ibáñez referred to 'equine athletes' in her statement following the CAS decision in Blythe and Lyle, FEI, Press Release: CAS upholds FEI Policy on Equine Provisional Suspensions, 23 March $2018<$ https://inside.fei. org/news/cas-upholds-fei-policy-equine-provisional-suspensions $>$ accessed 2 April 2019. 88 FEI, 'Welcome to FEI Clean Sport' <https://inside.fei.org/fei/cleansport> accessed 21 August 2019.

89 CAS 2012/A/2807 Khaled Abdullaziz Al Eid v Fédération Equestre Internationale/ CAS 2012/A/2808 Abdullah Waleed Sharbatly v Fédération Equestre Internationale, para 6.24
} 


\section{THE DENNING LAW JOURNAL}

athletes. ${ }^{90}$ The horse should be considered an athlete and not an inanimate object that can be viewed in the same way as 'equipment' used in human sports. ${ }^{91}$

\section{Strict Liability}

A violation of the EADCMRs is a strict liability offence (Article 2.1.1 of the EAD Rules). There is an irrebuttable presumption that provides that the 'Person Responsible' (PR), which includes the rider and support personnel in certain circumstances, is responsible for an adverse analytical finding (Article 2.2-2.8). It is not necessary to demonstrate intent, fault, negligence or knowing use of a prohibited substance. The inclusion of support personnel was a result of submissions and feedback from the various national federations in the lead up to the 2010 Regulations. The use or attempted use of a banned substance or a banned method is provided for under Article 2.2. Regarding the use of a banned substance, the PR has a personal duty along with support personnel to ensure than no prohibited substance enters the horse's body or that any banned method is used. However, in the case of attempted use of a banned substance or of a banned method, it is necessary to show intent. Success or failure of either the use or attempted use of a banned substance or method is irrelevant (Article 2.2.2).

In reference to control medication substances, it is a violation of the EADCMRs if the substance is present at the time of an event in absence of a valid Veterinary form (Article 2.1 of the ECM Rules). It should not be given to the horse close to or during an event 'unless the appropriate FEI guidelines for medication authorisation have been followed'. ${ }^{92}$ The FEI proffer that the ECM Rules are based on a

90 Jonathan Glen Merritt, “'Don't Look a Gift Horse in the Mouth”: Regulating for Integrity, What Equestrianism Can Learn from Thoroughbred Racing' (2017) 16 International Sports Law Journal 198, 201-202. The Introduction to the 2019 EADCM Regulations states that the Regulations "particularly as they apply to Banned Substances (the EAD Rules), have intentionally been modelled after the 2015 WADA Model Code for human athletes', EADCMRs (n 86) 2-3.

91 Ibid 200.

92 EADCMRs, Equine Controlled Medication Rules, 1 <https://inside.fei.org/sites/ default/files/EADCMRs\%20-\%20Effective\%201\%20January\%202019\%20-\%20 Final\%20Version_Clean\%20-\%20For\%20Publication_0.pdf $>$ accessed 7 April 2019. The FEI advocates a margin of safety in relation to the detection time of controlled substances and acknowledges that it is up to relevant veterinary surgeon as each horse is different; however, it stated in the case of a show jumper from Saudi Arabia that the safety margin should be multiplied by two, see Decision of the FEI Tribunal dated 24 March 2017, Positive Controlled Medication Case No.: 2016/CM04, para 5.2 (c) <https://inside.fei.org/ 


\section{THE FÉDÉRATION EQUESTRE INTERNATIONALE SPEAKS FOR THE HORSE WHO HAS NO VOICE AND THE COURT OF ARBITRATION}

distinctive and core characteristic of the human/horse partnership that equestrianism imbues, namely that the horse is unable to speak and it is the role of the FEI to protect the horse:

It is therefore the FEI's responsibility to speak on its behalf, and to ensure that, at every stage of the governance, regulation, administration and practice of the sport, the welfare of the Horse is paramount ... all treatments must be given in the best health and welfare interests of the Horse, and not for any other reasons. ${ }^{93}$

Under the ECM Rules a controlled medication may be given to a horse, however, it must be 'fully justifiable based on the medical condition of the horse'. ${ }^{94}$ If a horse is unable to compete due to injury or disease, the horse must be provided with appropriate veterinary treatment and rest (or recovery period). ${ }^{95}$ While there is some flexibility with regard to controlled medication (subject to certain conditions), a prohibited substance is a violation of the EAD Rules.

The burden of proof that an adverse analytical finding has occurred under the EAD Rules is placed on the FEI under Article 3.1. This article further provides:

Where these EAD Rules place the burden of proof upon the Persons Responsible and/or member of their Support Personnel to rebut a presumption or establish specified facts or circumstances, the standard of proof shall be by a balance of probability, except where a different standard of proof is specifically identified.

The standard of proof placed on the FEI is to demonstrate to the comfortable satisfaction of the Hearing Panel taking into account the seriousness of the alleged doping infraction. In line with the WADA code, the standard of proof in all cases is greater than a mere balance of probability, but less than proof beyond a reasonable doubt. In relation to the ECM Rules, the burden of proof is placed on the FEI, however, the standard is that of the balance of probabilities (Article 3.1). ${ }^{96}$

system/files/2016-CM04\%20-\%20AD\%20ARGOS\%20-\%20Final\%20Tribunal\%20 Decision\%20-\%2024\%20March\%202017.pdf>

${ }^{93}$ Ibid.

94 Ibid.

95 Ibid.

96 This article further provides: 'Where these ECM Rules place the burden of proof upon the Persons Responsible and/or member of their Support Personnel to rebut a presumption 
In effect, the standard of liability imposed by sports governing bodies, including the FEI, regarding banned substances is harsher than that in criminal law and reverses the normal burden of proof. ${ }^{97}$ Consequently, the FEI and the CAS use a quasi-criminal principle but apply the civil standard of the balance of probabilities and not the criminal standard of beyond reasonable doubt. Strict liability is a principle used in both criminal and civil law. Strict liability in tort law applies, for example, to product liability, ultra hazardous activities (such as blasting), cattle trespassing on land and the possession of wild animals. In relation to ultra hazardous activities, the plaintiff, as a rule, does not need to establish negligence where the tortfeasor has engaged in an abnormally dangerous activity. ${ }^{98}$ Ashworth contends that criminal law textbooks present a 'paradox' as these books highlight the need for the 'mens rea' which is a 'moral and legal requirement for conviction ... yet Irish criminal law, like English criminal law, contains many offences that depart from that standard by imposing a form of strict liability'. ${ }^{99}$ The majority of strict liability offences, often referred to as public welfare offences or moral crimes, carry low prison time, attach little stigma and it is more prudent from an economic perspective to deal with the matter as expeditiously as possible. ${ }^{100}$ A number of Continental European countries have created a separate category of administrative offences which attract low penalties and are dealt with efficiently and speedily. ${ }^{101}$

It is difficult to reconcile the public welfare argument to equine doping. Criminal strict liability was introduced to protect factory workers following the Industrial Revolution. With the Industrial Revolution came the large-scale production of foodstuffs and criminal strict liability applied to the sale of adulterated foods and drinks and the sale of alcohol to minors. ${ }^{102}$ Ascribing the term moral offence is perhaps more accurate in equine doping cases. The equine athlete is a sentient being who relies on humans to ensure their safety and

\footnotetext{
or establish specified facts or circumstances, the standard of proof shall be by a balance of probability, except where a different standard of proof is specifically identified'.

97 Laura Donnellan, 'Strict liability in Drug Cases' (2002) 9(6) Sports Law Administration and Practice 13.

98 Liebman (n 47) 26.

99 Andrew J Ashworth, Positive Obligations in Criminal Law (A \& C Black, 2014), Essay 4: Should Strict Criminal Liability Be Removed from All Imprisonable Offences?

100 Ibid. Some crimes, such as statutory rape and possession crimes, are strict liability offences even though they are serious offences. Statutory rape is a moral crime and the defendant is responsible due to the age of the victim, Liebman (n 47) 26.

101 Ibid.

102 Ibid., 30.
} 
well-being. They are in an extremely vulnerable position as they are unable to verbalise and depend on their human custodians to act in their best interests. By applying a strict liability standard, the PR is responsible for any unauthorised substance that the horse ingests. Parallels can be drawn with the English case from the High Court of Justice Chancery Division, Gasser $v$ Stinson. ${ }^{103}$ Gasser was a Swiss athlete who tested positive for a banned substance. She challenged, inter alia, the validity of the testing methods and the strict liability standard. Gasser contended that a malicious prankster could interfere with an athlete's food and the athlete could innocently ingest a banned substance. While sympathetic to her plight, Justice Scott upheld the strict liability standard on the grounds that to hold otherwise would open the floodgates and render ineffective the drug testing policies of sporting bodies. Over time WADA has relaxed the strict liability standard in relation to human athletes. As the CAS decision in Ahlmann shows, the CAS takes into account both mitigating and aggravating factors.

In the Ahlmann case, the FEI contended that the 'FEI Tribunal erred in its approach when it decided that in the presence of a substance with hypersensitising as well as pain-relieving qualities, the FEI must prove more than the mere existence of the substance'. ${ }^{104}$ In effect, the FEI Tribunal was undermining the FEI's standard of strict liability. The CAS Panel rejected this contention and noted:

that the FEI rules put in place a system according to which the mere presence of a prohibited substance in the horse's body constitutes a rule violation regardless of its concentration, its performance-enhancing effects or its origin, and that the PR is responsible for any such prohibited substance found to be present in the horse's bodily samples. ${ }^{105}$

Ahlmann argued that the FEI strict liability standard was a breach of Article 7 of the Swiss Cartel Law; the CAS Panel rejected this contention and pointed to the lack of evidence or market analysis to demonstrate that the FEI was abusing its dominant position. ${ }^{106}$ The CAS Panel found Ahlmann's argument vague and

103 Sandra Gasser v Henry Robert Hunter Stinson and John Bryan Holt (Unreported, High Court of Justice Chancery Division, Scott J, 15 June 1988).

104 Ibid., para 33.

105 CAS (n 56) para 84.

106 Ibid., para 86. 
unsupported by economic evidence. ${ }^{107}$ The CAS reiterated the compatibility of strict liability with Swiss Law:

.... that the FEI disciplinary system is indeed compatible with the principles and statutes of Swiss law. Importantly, the Swiss Federal Court has recently ruled that this disciplinary system, based on strict liability, is fully justified in equestrian sport by prevailing public interest, as the fight against doping tends to safeguard parity among competitors and fairness of competitions, protect the animals' health, maintain breeding quality, combat the use of dangerous substances, preserve the integrity of the sport, and ensure that a good example is set for young people. These objectives are unanimously recognised by sports organisations and government institutions. (ATF 134 III 193, p. 203, para. 4.6.3.2.2; in the same sense, see CAS 2008/A/1569 Kürten v/FEI paras. 7.6 7.7; CAS 2008/A/1654 B. Alves v/FEI, paras. 5.18-5.23) ${ }^{108}$

The CAS Panel dismissed Ahlmann's argument that the List of Prohibited Substances was 'unclear, misleading and has not been adapted to scientific and technical progresses.' ${ }^{109}$ The fact that the FEI Tribunal erred in finding that capsaicin was a controlled medication and not a prohibited substance is evidence that the regulations were confusing and needed to be clarified. The CAS Panel did not engage in any detailed discussion as to the lack of coherency in the regulations. Although, following the Ahlmann case, the FEI, as discussed above, endeavoured to introduce a more cohesive set of anti-doping regulations.

Most recently, the CAS upheld the FEI's application of the principle of strict liability to equine doping cases. In Sheik Hazza Bin Zayed Al Nahyan v FEI, counsel for the appellant proposed that:

the EAD Rules should be interpreted in a manner which allowed a rider to rebut a presumption of strict liability arising from a positive test on a horse and be held not to have committed a violation, if he or she could show that he or she had no knowledge or means of knowing of or controlling the conduct that brought about the violation. ${ }^{110}$

\footnotetext{
107 Ibid.

108 Ibid., 85.

109 Ibid.
}

110 CAS 2014/A/3591, 8 June 2015, para 49. The decision is not available on the CAS database. It can accessed from the FEI website <https://inside.fei.org/system/files/ Final\%20CAS\%20Decision $\% 20-\% 20$ Sheik $\% 20$ Hazza $\% 20$ A $1 \% 20$ Nayan $\% 20 v s \% 20$ FEI\%20-\%208\%20June\%202015_0.pdf> accessed 4 August 2019. 


\section{THE FÉDÉRATION EQUESTRE INTERNATIONALE SPEAKS FOR THE HORSE WHO HAS NO VOICE AND THE COURT OF ARBITRATION}

The appellant challenged the strict liability on the grounds that it was 'an affront to morality and public policy'. ${ }^{111} \mathrm{He}$ accepted that the standard was appropriate for human athletes who, in most situations, have autonomy over their bodies and make conscious decisions as to what they ingest. ${ }^{112}$ Riders, he reasoned, 'necessarily have less control over what goes into the horses body'. ${ }^{13}$ The appellant submitted that strict liability was disproportionate, unjustified and constituted a breach of his fundamental rights under Swiss Law, EU Law, including EU competition law. ${ }^{114}$ The CAS Panel referred to a sporting body's 'margin of appreciation in making rules to regulate the conduct of its members.' ${ }^{15}$ The sporting body, generally, is in the best position to decide the applicable rules. The CAS Panel found that the strict liability standard 'is justified in the public interest in the fight against doping in sport'. ${ }^{116}$ Parallels can be drawn between the approach of the CAS in equine doping cases and the Gasser case. Scott $\mathrm{J}$ in Gasser referred to the judgement of Megarry $\mathrm{J}$ in McInnes $v$ Onslow-Fane where the court set out the position of the governing bodies and the creation and development of their own rules and regulations:

I think that the courts must be slow to allow any implied obligation to be fair to be used as a means of bringing before the courts for review honest decisions of bodies exercising jurisdiction over sporting and other activities which those bodies are far better fitted to judge than the courts. ${ }^{117}$

It is clear from the jurisprudence of the CAS in equine doping cases that strict liability is proportionate, can be justified in the public interest, it does not breach fundamental rights and is an appropriate standard to ensure that the welfare of the equine athlete is protected. There is a moral and legal duty on the FEI to safeguard its core values. In short, it is within the preserve of the FEI to determine its own rules and regulations. However, these rules and regulations need to clear and there should be no ambiguity.

\footnotetext{
111 Ibid., para 69.

112 Ibid.

113 Ibid., para 71.

114 Ibid., para 144.

115 Ibid., para 149.

116 Ibid., para 158

117 [1978] 1 WLR 1520, 1535. This case concerned a refusal by the British Boxing Board of Control (BBBC) to allow an oral hearing and the furnishing of prior information as to the case against the plaintiff who had applied unsuccessfully five times for a licence.
} 


\section{SHOULD THE STANDARD OF STRICT LIABILITY BE RELAXED?}

The FEI and the CAS have consistently upheld the strict liability standard on the grounds of fairness of competition and animal welfare. PRs, on the other hand, have challenged it on the grounds of proportionality and an infringement of fundamental rights. The strict liability approach of the FEI has been criticised on the grounds that 'there is a fine line ... between the need to protect the horse and cases where the strict liability is going too far as to be no longer concerned with clean sports. ${ }^{118}$ Thus, the line is even more pronounced when cognisance is given to the fact that the horse's food could be contaminated or another horse's presence in the stable results in the horse 'picking up' up traces of contaminated medication. ${ }^{119}$ British lawyer, Jeremy Dickerson contends that the bar is set too high as there are grey areas especially when it comes to contaminated foodstuffs. ${ }^{120}$ He advocates the introduction of 'a lower fixed penalty where inadvertent contamination is proved or, better still, a sliding scale of 0-6 months'. ${ }^{121}$

A study carried out by Swiss-based researchers found that, in samples taken from 28 types of horse feed, 18 tested positive for prohibited and controlled substances. ${ }^{122}$ In situations of contamination, the PR must prove, on the balance of probabilities, that the inadvertently ingested substance was the result of contamination and if this can be proved, the period of ineligibility may be eliminated or reduced under Article 10.4 of the ECM Rules. ${ }^{123}$

118 Ester Herlin-Karnell, 'EU Sports Law and the Equestrian World: A Galloping Area of Increasing Importance' (2013) 13 International Sports Law Journal 168.

119 Ibid.

120 Neil Clarkson, 'Bar Set Too High in FEI Doping Cases, Lawyer Believes' (Horse Talk, 9 September. 2014) <https://www.horsetalk.co.nz/2014/09/09/bar-set-too-high-fei-dopingcases-lawyer-believes/?share=email > accessed $30 \mathrm{Jul} 2019$.

121 Ibid.

122 The findings were published online in German, with the abstract in English (C Herholz, N Zink, H Laska, M Gumpendobler, Charles Trolliet and S Probst, 'Dopingrelevante Substanzen in Futtermitteln für Pferde' (2017) 159(4) Schweiz Arch Tierheilkd 231, DOI: <https://doi.org/10.17236/sat00112> accessed 21 August 2019. The findings were translated into English by Laura Donnellan and a summary of the study can be found at Laura Donnellan, 'Equestrianism: Swiss Researchers Find 64\% of Horse Feed Contains Prohibited or Controlled Substances!' (Sportsandtaxation.com, 29 August 2017) $<$ https://www.sportsandtaxation.com/2017/08/equestrianism-swiss-researchers-find-64of-horse-feed-contains-prohibited-or-controlled-substances $>$ accessed 7 Aug. 2019.

123 In the DECISION of the FEI TRIBUNAL dated 20 February 2014 Positive Controlled Medication Case No.: 2013/FT02 Honky Tonk Whiz, the PR could not prove that the 


\section{THE FÉDÉRATION EQUESTRE INTERNATIONALE SPEAKS FOR THE HORSE WHO HAS NO VOICE AND THE COURT OF ARBITRATION}

Merritt raises an interesting argument. He posits that the decisions of the FEI Tribunal and the CAS which have continually endorsed the strict liability standard is 'unconscionable' and 'reverse burdens should be applied in equine cases because the infraction happens in the body of a non-autonomous nonhuman athlete but the sanction is applied to the mind of an athlete of a different species'..$^{124}$

The BHA's anti-doping rules are based on the underlying principle of strict liability, which has been:

adopted by all signatories to Article 6 of the International Federation of Horseracing Authorities' (IFHA) International Agreement. Equine antidoping rules are in place to provide a level playing field for all competitors, and to ensure that substances which may have the capacity to effect performance or impact on a horse's welfare are not administered to horses involved in our sport. ${ }^{125}$

The argument that the regulatory bodies of horseracing and equestrian sport use strict liability and thus strict liability is the norm is a weak argument on its own. The position of the horse can be compared to that of a minor, albeit a human autonomous athlete. The PR is in a guardian position and it is up to them to ensure that the horse does not ingest a banned substance and follows the regulations with regard to controlled medications. It is up to the PR to ensure that a product does not contain any prohibited substance by seeking veterinary advice, looking up the prohibited substance database on the FEI website or downloading the FEI app. ${ }^{126}$

In the current state of affairs, the continued application of strict liability should remain the underlying principle in order to protect equine welfare. If the FEI were to move away from the principle, the EADCMRs would be undermined. As the horse is unable to speak for themselves, there should be a higher duty of care placed on the PR to ensure that the horse does not ingest a banned or controlled

positive test for controlled medication was the result of contamination, $<$ https://inside.fei. org/system/files/Case_2013_FT02_HONKY_TONK_WHIZ_Final_Tribunal_ Decision_20_February_2014.pdf $>$ accessed 9 August 2019.

124 Merritt (n 91) 281.

125 BHA Press Release, 'BHA Seeks Rule Change on Anti-doping Penalties' (23 November 2017) < https://www.britishhorseracing.com/press_releases/bha-seeks-rule-change-antidoping-penalties $>$ accessed 8 August 2019.

126 FEI, 'Clean Sport for Horses - FEI Prohibited Substances List' < https://inside.fei.org/ fei/cleansport/ad-h/prohibited-list> accessed 3 August 2019. Information on the mobile apps can be found at: FEI, 'Mobile Apps', <https://inside.fei.org/fei/cleansport/horses/ mobile-apps> accessed 21 August 2019. 
substance. The FEI Tribunal and the CAS take into account mitigating and aggravating factors when it comes to the sanctions imposed, thus there is some flexibility without moving away from strict liability.

Dickerson's suggestion of a sliding scale of penalties in situations involving contaminated food is welcome. The Swiss based research was undertaken in response to three high profile failed drug tests in 2015, involving two Swiss jumping riders whose horses tested positive for banned and controlled substances. ${ }^{127}$ The two riders, Guerdat and Bichsel, were subsequently cleared when it was found that the failed tests were attributed to poppy seed contamination of their horses' food. At an event in France in May 2015, Guerdat's mount, Nino des Buisonnets, tested positive for the banned substances of codeine and oripavine, and morphine, a controlled substance. At the same event, Guerdat had ridden Nasa, whose sample yielded an adverse analytical finding for codeine and morphine. Nasa's sample also contained trace amounts of oripavine; however, the amount found was not of the requisite level for a doping infraction to have been committed.

In July 2015 Guerdat and Bichsel were informed by the FEI that their respective horses had tested positive for banned and controlled substances. The FEI informed the riders that the samples tested at the FEI-accredited LGC Newmarket Road Laboratory in Cambridgeshire, UK, had been found to contain prohibited substances under Article 2.1 of the Equine Anti-Doping Regulations. ${ }^{128}$

Both riders had their suspensions lifted as the FEI Tribunal was satisfied that the positive tests were the result of contaminated horse feed. ${ }^{129}$ However, the two-month suspension placed on the horses was upheld on the grounds of animal welfare, which is an established policy of the FEI, as will be discussed below. Both riders appealed the two-month suspension of their horses; however, the FEI Tribunal dismissed the appeals, with leave to appeal to the Court of Arbitration for Sport (CAS) within 21 days of the decision. The riders also had the results achieved at the events quashed, including the forfeiture of medals, points and prizes.

\footnotetext{
127 Donnellan (n 124).

128 Alessandra Bichsel/SUI, 'Decision of the FEI Tribunal' (25 September 2015) <https:// inside.fei.org/system/files/2015-BS04\%20-\%20CHARIVARI\%20KG\%20-\%20FEI\%20 Tribunal\%20Decision\%20-\%2025\%20September\%202015.pdf $>$ and Steve Guerdat/SUI, 'Decision of the FEI Tribunal' (18 September 2015) <http://inside.fei.org/system/files/ Case $\% 202015-B S 02 \% 20-\% 20$ NASA $\% 20-\% 202015-B S 03 \% 20-\% 20$ NINO\%20DES\%20 BUISSONNETS \%20-\%20Final\%20Tribunal\%20Decision $\% 20-\% 2018 \% 20$ September\%202015.pdf $>$ accessed 10 August 2019.

129 FEI, 'Steve Guerdat and Alessandra Bichsel cleared of wrongdoing by FEI', 28 September 2015, <https://inside.fei.org/news/steve-guerdat-and-alessandra-bichselcleared-wrongdoing-fei> accessed 23 August 2019.
} 


\section{THE FÉDÉRATION EQUESTRE INTERNATIONALE SPEAKS FOR THE HORSE WHO HAS NO VOICE AND THE COURT OF ARBITRATION}

The study carried out by the Swiss scientists examined domestically produced food as well as imported horse food, with 16 samples taken from food manufactured outside Switzerland and 12 from Switzerland. ${ }^{130}$ The commercial feed was found to have traces of nine banned and controlled substances under the FEI's EADCMRs. All nine substances originate from plants, trees, leaves or seeds that are found in nature. The researchers interestingly found that poppy seeds, which were harvested using machinery, had a higher concentration of morphine than poppy seeds processed by hand. ${ }^{131}$ The study concluded that, even with the most careful and up-to-date methods of processing, horse feed can be easily contaminated by prohibited and controlled substances. In all the samples analysed, the amount was not of a level that would adversely affect a horse's health.

While the study has demonstrated the prevalence of contaminated horse feed, the FEI has an established policy of suspending the horse for two-months on the grounds of animal welfare. Going forward, any future incidences of contaminated horse feed will most likely exonerate the rider with the exception of their forfeiting qualifications/records/medals/prizes; the welfare of the horse will remain a concern for the FEI.

The requirement of a more rigorous testing of food to be carried out before a horse is fed would be both costly and arduous, given that feed, such as hay, is a staple of the horse's diet. The study did not state what other countries were involved in the analysis; it is not clear whether they were EU-based companies or outside the EU or a mixture of both. The result of $64 \%$ of the samples containing prohibited and controlled substances is worrying; however, Dr Herholz, one of the researchers, contends that the amounts were so minute that, in the case of morphine found in one oat sample, 'in order for the horse to have a visibly bodily reaction, he would need to consume 2,083 kilograms (more than 4,500 pounds) of those oat grains'. ${ }^{132}$ In the study, the researchers contend that a $500 \mathrm{~kg}$ horse would need to ingest 250 $\mathrm{mg}$ of morphine in order for it to have any effect. ${ }^{133}$

With the effect on the horse aside, the strict liability nature of equine doping means that an adverse analytical finding constitutes a doping infraction and it is conceivable that contaminated hay could result in a two-month suspension of a horse, as well as the consequences for the rider in relation to forfeiture of results. In light of the findings of the study, contaminated food is an area in which the

\footnotetext{
130 Herholz et al. (n 123) 232.

131 Ibid., 233-234.

132 Christa Lesté-Lasserre, 'Study Evaluates Banned, Controlled Substances in Horse Feed' (The Horse, 15 August 2017) < http://www.thehorse.com/articles/39549/studyevaluates-banned-controlled-substances-in-horse-feed> accessed 12 August 2019.

133 Herholz et al (n 123) 234.
} 
reversal of burdens could be used and thus a move away from the harshness of strict liability.

Along with strict liability, the FEI provides for two-month provisional suspension of horses in order to ensure fairness of competition and equine welfare. The two-month provisional equine suspension was the subject of an appeal to the CAS, wherein the CAS upheld its validity and has ensured, for the foreseeable future that it is immune from further challenge. It is to this issue the article now turns.

\section{Two-Month Provisional Suspensions for Equine Athletes}

The two-month provisional suspension for equine athletes is not defined in the EADCMRs. There is no information on the FEI website. The CAS in Blythe and Lyle refer to a 2012 resolution providing for the two-month equine suspension, which was evidenced by the minutes of a FEI Executive Board meeting dated 5-6 May 2012. ${ }^{134}$ Outside of this reference, there is no information on the procedural history of the two-month equine suspension. It is clear from the FEI's Annual Report 2012, that two-month provisional equine suspensions were recorded for the first time. ${ }^{135}$ Subsequent reports refer to the two-month provisional equine suspensions. ${ }^{136}$

According to the Regulations, when an adverse analytical finding relating to a banned or controlled substance is discovered, the PR is automatically provisionally suspended from the date of notification from the FEI. The horse is suspended for two-months. Provisional suspensions are found under Article 7.4 and are placed on the PR pending a full hearing. ${ }^{137}$ Where the PR requests the lifting of the provisional suspension, the FEI Tribunal will maintain the provisional suspension unless the PR establishes to the comfortable satisfaction of the FEI Tribunal that (Article 7.4.4):

i. the allegation of an EAD violation has no reasonable prospect of being upheld due to a material defect in the evidence on which the allegation is based; or

\footnotetext{
134 CAS 2017/A/5114 (n 13).

135 FEI, 'Annual Report 2012', 72, <https://inside.fei.org/system/files/FEI\%202012\%20 AR\%20spreads.pdf $>$ accessed 8 April 2019: 'In addition, all horses which tested positive for Banned Substances were provisionally suspended for a period of two (2) months, starting on the date of the Notification Letter'.

136 FEI Annual Reports 2004 to 2017 are available at <https://inside.fei.org/fei/about-fei/ publications/fei-annual-report $>$ accessed 8 April 2019.

137 For more details on the requirements and procedures, see (n 80) 7.4.1-7.4.7.
} 
ii. the PR can demonstrate that the evidence will show that s/he bears No Fault or Negligence for the violation of the rule that is alleged to have been committed, so that any period of ineligibility that might otherwise be imposed for such a violation is likely to be completely eliminated by application of Article 10.4 (Elimination of the Period of Ineligibility Where There Is No Fault or Negligence) or Article 10.5 applies (Elimination of the Period of Ineligibility Where There Is No Fault or Negligence) and the PR has already been provisionally suspended for a period of time that warrants the lifting of the provisional suspension pending a final decision of the FEI Tribunal; or ${ }^{138}$

iii. exceptional circumstances exist that make it clearly unfair, taking into account all of the circumstances of the case, to impose a Provisional Suspension prior to the final hearing of the FEI Tribunal. This ground is to be construed narrowly, and applied only in truly exceptional circumstances. For example, the fact that the Provisional Suspension would prevent the Person or Horse competing in a particular Competition or Event shall not qualify as exceptional circumstances for these purposes. ${ }^{139}$

According to the EAD Rules, the FEI may also request the lifting of the Provisional Suspension. As discussed, the FEI adopts the strict liability standard, the exceptions show that there is flexibility and discretion when it comes to lifting provisional suspensions.

The 2019 EAD Rules provide for a reduction of sanctions for specified substances and contaminated products (Article 10.5.1). The FEI insists that specified substances are not to be viewed as less important or less dangerous than other prohibited substances. It recognises that a horse could ingest a substance through contaminated food. If a horse tests positive for a specified substance, the application of a provisional suspension is not automatic. ${ }^{140}$

Article 10.4 (Elimination or the Period of Ineligibility Where There Is No Fault or Negligence) may also be used in cases involving specified substances, however, it will not apply in situations where:

a. the presence of the Banned Substance in a Sample came from a mislabelled or contaminated supplement. Persons Responsible are responsible for what their

\footnotetext{
138 The 2019 rules insert the following after FEI Tribunal: 'This Article 7.4.4(ii) does not apply to an application to lift a Provisional Suspension imposed on a Horse'.

139 Article 8 provides for a Right to a Fair Hearing.

140 Press Release, 'FEI Tribunal lifts provisional suspensions' (10 May 2017) <http:// inside.fei.org/news/fei-tribunal-lifts-provisional-suspensions> accessed 6 April 2019.
} 
horses ingest and have been warned about the possibility of supplement contamination.

b. the Administration of a Banned Substance by the Person Responsible' s veterinary personnel or member of the Support Personnel without disclosure to the Person Responsible. Persons Responsible are responsible for their choice of veterinary personnel and Support Personnel and for advising veterinary personnel and Support Personnel that Horses cannot be given any Banned Substance at any time.

Article 10.5 on the Reduction of the Period of Ineligibility based on No Significant Fault or Negligence can also be used in cases involving specified substances. At a minimum, the PR faces a reprimand but no period of ineligibility and a maximum of a two-year period of ineligibility depending on the degree of fault. The same penalties apply under Article 10.5.1 on the Reduction of Sanctions for Specified Substances and Contaminated Products.

The FEI rules provide for recourse to the Court of Arbitration for Sport (Article 12.3) which provides that an appeal may be made within 21 days of the appealing party being notified of the decision of the Hearing Panel.

\section{The Lifting of Provisional Equine Suspensions}

On 10 May 2017, the FEI announced in a Press Release that it had lifted the provisional suspensions of eleven athletes: two Jumping, two Dressage and seven Endurance and three Endurance trainers. Two international Showjumping athletes, Marlon Modolo Zanotelli from Brazil and Henry Turrell of Great Britain had their suspensions lifted on 27 April 2017. Both competitors' horses tested positive for the banned substance Sparteine. ${ }^{141}$ Zanotelli and Turrell were competing in separate events in Vilamoura, Portugal which took place from 20 to 26 February 2017. ${ }^{142}$ Sparteine is classified as an anti-arrhythmic and 'is not used therapeutically in horses. ${ }^{143}$ Sparteine is derived from the lupin flower, and of particular

\footnotetext{
141 It is classified as a banned substance under the 2019 EPSL (n 77).

142 Zanotelli was notified of his provisional suspension on 5 April 2017, FEI Press Release, 'Prohibited Substance Cases under FEI Anti-Doping Rules', 6 April 2017 <https://inside. fei.org/news/prohibited-substance-cases-under-fei-anti-doping-rules $>$ accessed 6 April 2019. Turrell was notified of his provisional suspension on 18 April 2017, FEI Press Release, 'Prohibited Substance Cases under FEI Anti-Doping Rules', 26 April 2017 $<$ https://inside.fei.org/news/prohibited-substance-cases-under-fei-anti-doping-rules-0> accessed 6 April 2019.

143 'Two More Riders Suspended in Prohibited Substance Cases under the FEI
} 


\section{THE FÉDÉRATION EQUESTRE INTERNATIONALE SPEAKS FOR THE HORSE WHO HAS NO VOICE AND THE COURT OF ARBITRATION}

importance to this case was the fact that the lupin flower is prevalent in Portugal where the event took place. The FEI Tribunal was influenced by both the scientific evidence adduced by the two competitors that food contamination was the reason behind the adverse analytical finding and the recommendation by the FEI Equine Prohibited Substances List Expert Group, who annually review the EPSL, that Sparteine be placed on the Controlled Medication and Specific Substance List by January 2018. ${ }^{144}$

In February 2017, it was announced that seven horses tested positive at United Arab Emirates (UAE) Endurance events which took place at the Al Wartha venue in Abu Dhabi between the end of November 2016 and January 2017. The horses were tested at four separate events. ${ }^{145}$ Four prohibited substances were found in the samples of the seven horses. ${ }^{146}$ In the wake of the announcement, the FEI Secretary General Sabrina Ibáñez noted that it was the first time that the FEI had suspended the trainers at the same time as the athletes and observed that when there are a number of breaches by the same trainer it demonstrates that there is 'something wrong with the stable management'. ${ }^{147}$ The FEI Secretary General stated:

We take all breaches of the FEI anti-doping regulations extremely seriously and these latest positives demonstrate clearly that those using prohibited substances will be caught ... Suspending the trainers immediately, rather than

\footnotetext{
Anti-doping Rules' (World of Showjumping, 25 April 2017) <http://www. worldofshowjumping.com/en/News/Two-more-riders-suspended-in-prohibitedsubstance-cases-under-FEI-anti-doping-rules.html> accessed 6 April 2019. This article also refers to a South African rider whose horse tested positive for paracetamol, also a banned substance.

144 FEI, 'FEI Equine Prohibited Substances List Expert Group' < https://inside.fei.org/fei/ your-role/veterinarians/suggest-a-change>accessed 21 August 2019.

145 The four athletes and four trainers were informed of their provisional suspensions on 30 January 2017. The horses were suspended for two months from the same date. FEI Press Release, 'Prohibited Substance Cases under FEI Anti-Doping Rules', 3 February $2017<$ http://inside.fei.org/news/new-prohibited-substances-cases-under-fei-anti-dopingrules $>$ accessed 7 April 2019.

146 Ibid. The Press Release stated that: 'All seven horses have tested positive to the same four prohibited substances, the stimulant Caffeine and its metabolites Theophylline, Theobromine and Paraxanthine. Equally, Theophylline, used for the treatment of asthma and various respiratory diseases, can be metabolised to Caffeine. One of the horses also tested positive to the corticosteroid Flumetasone, which is used in the treatment of skin disorders'.

147 Ibid.
} 
waiting until the athlete has been prosecuted, confirms that the FEI will not tolerate any attempts to enhance the performance of the horse. ${ }^{148}$

\section{Interim Decision of the Court of Arbitration for Sport}

Included in the eleven provisional suspensions were two US Dressage athletes Adrienne Lyle, an Olympic rider and Kaitlin Blythe, an under-25 competitor. Both athletes were provisionally suspended on 5 April $2017 .{ }^{149}$ Their horses tested positive for the banned substance Ractopamine after samples were taken during Week 5 of the Adequan Global Dressage Festival that took place between December 2016 and February 2017 in Wellington, Florida. Ractopamine is a beta adrenoceptor agonist which was recently used in tests involving pigs and was found to 'improve growth performance and carcass composition in pigs.' ${ }^{150}$ Both positive tests were recorded during Week 5 of the Festival. However, it was reported that the substance is widely added to horse feed in America. ${ }^{151}$ The athletes argued that the substance fell within the definition of Specified Substance, as outlined above.

The United States Equestrian Federation (US Equestrian) on its website commended the makers of the drug, Cargill, for its admission that the positive test resulted from a contaminated nutritional supplement. ${ }^{152}$ US Equestrian acknowledged that the substance, which is legal in the US, is banned in over 160 countries, including the 28 Members of the European Union, China and Russia

\footnotetext{
148 Ibid.

149 On 27 April 2017, urine and blood samples from the horses were tested to see if any trace of Ractopamine remained in the horses' systems. The Maddy Equine Analytical Chemistry Laboratory at the University of California, Davis, found no presence of the substance in either horses' samples.

150 This can be found on the search database on the FEI website: <http:// prohibitedsubstancesdatabase.feicleansport.org/search-results $>$ accessed 7 April 2019. See also Kenneth J Braddick, 'USA Olympic Rider Adrienne Lyle, Under-25 Rider Kaitlin Blythe Provisionally Suspended for Prohibited Substance Found in Horses' (DressageNews, 6 April 2017) <http://www.dressage-news.com/2017/04/06/usa-olympic-rideradrienne-lyle-under-25-rider-kaitlin-blythe-provisionally-suspended-for-prohibitedsubstance-found-in-horses> accessed 7 April 2019.

151 Ibid.

152 US Equestrian Communications Department, 'Cargill Acknowledges Contamination of Feed Supplement Caused Positive Test Results' (US Equestrian, 9 May 2017) <https:// www.usef.org/media/press-releases/cargill-acknowledges-contamination-of-feedsupplement-caused-positive-test-results> accessed 7 April 2019.
} 


\section{THE FÉDÉRATION EQUESTRE INTERNATIONALE SPEAKS FOR THE HORSE WHO HAS NO VOICE AND THE COURT OF ARBITRATION}

'due to its controversial and adverse effects in cattle and swine'. ${ }^{153}$ Cargill announced the following on its website:

Through our investigation, we identified that Progressive Nutrition ${ }^{\circledR}$ Soothing Pink $^{\mathrm{TM}}$, a nutritional supplement used to prevent gastric upset, contained an ingredient that included trace amounts of Ractopamine. Upon learning of this trace finding, we immediately withdrew our Progressive Nutrition ${ }^{\circledR}$ Soothing Pink ${ }^{\mathrm{TM}}$ product from the market. At this time, we have identified and isolated the ingredient that was the source of the contamination and we have completely stopped use of the ingredient in all products. ${ }^{154}$

The two athletes had their provisional suspensions lifted on 28 April 2017; however, the FEI Tribunal upheld the two-month suspension of their horses, Horizon and Don Principe, on the grounds of animal welfare and in order to ensure a level playing field. Both athletes challenged the decision of the FEI Tribunal before the CAS. Given the urgency of the matter, written submissions were furnished, and an interim decision was made on foot of the documentation supplied. There was no oral hearing and there no mention of the interim order on the CAS website. A spokesperson for the CAS was quoted by Horse and Hound as stating:

This is a temporary decision, which is made pending the resolution of the CAS arbitration . . . These interim decisions are not published by our tribunal but the final decision will be ... Given the urgency, no hearing took place but the parties concerned were able to express their position in writing. ${ }^{155}$

The CAS interim decision was disappointing. The decision of the CAS to grant interim relief seemed at odds with the FEI's core tenet of speaking for the horse who has no voice. The equine athletes were permitted to compete at the US Dressage Festival of Champions from 18 to 21 of May, thus the suspensions of Horizon and Don Principe were lifted in time for the event, which undermined the

\footnotetext{
153 Ibid. It is used in the United States for building muscle and size in pigs, turkeys and cattle.

154 Statement from Cargill, 'Trace amounts of Ractopamine found in Soothing Pink ${ }^{\mathrm{TM}}$ product', 3 May 2017 <http://store.nancoecipn.com/news.aspx> accessed 7 April 2019.

155 Lucy Elder, 'Dressage Riders' Suspensions Lifted: Contamination Blamed for Positive Drug Tests' (Horse and Hound, 11 May 2017) <http://www.horseandhound.co.uk/news/ kaitlin-blythe-adrienne-lyle-ractopamine-contamination-620471\#SPTUf1gp8P8iki9I.99> accessed 6 April 2019.
} 
decision of the FEI Tribunal. The FEI explicitly states in its EPSL that Ractopamine has 'no legitimate use' and the fact that 160 countries have banned the substance would suggest that it is a hazard to the health of horses.

\section{Court of Arbitration for Sport: Validity of Provisional Suspensions}

In November 2017, a full hearing took place before the CAS Panel, which included Michael Beloff QC as President of the Panel. The appellants proffered that Article 7.4.4 (iii) (as outlined above) applied as their situation was an 'exceptional circumstance' for the following reasons: the low level of Ractopamine detected, by the time the decision was appealed; there was no trace of Ractopamine in the horses' systems; the appellants had been cooperative in finding the source of the Ractopamine and responded to issues raised by the FEI; there was no scientific evidence to support that a horse competing during the two-month suspension would compromise animal welfare nor could it be shown that competing at the time (during the two-month suspension) would have yielded a competitive advantage by the earlier ingestion of Ractopamine; veterinary experts found no adverse effects on the horses in the first five months of 2017 and the level of support provided by the US Dressage Committee to the appellants. ${ }^{156}$ The appellants further contended that the two-month suspension imposed by the FEI was not properly authorised and was inconsistent with the EADs.

The FEI responded by holding that the two-month provisional suspension is within the EADs, the appellants had not shown that the 'exceptional circumstances' of Article 7.4.4 (iii) applied and that the imposition of provisional suspensions was legal, justified, proportionate and fundamental in protecting the welfare of the horse and ensuring a level playing field. ${ }^{157}$ The FEI argued that the appellants could not rely on Article 7.4.4 (i).

The CAS Panel conducted the hearing de novo thus it would decide the appeal on the evidence before it. ${ }^{158}$ It examined the reasons behind the FEI's two-month suspension: animal welfare, ensuring a level playing field, deterrence and damage to the image of the sport if previously doped horses could compete. ${ }^{159}$ The Panel contended that first ground was sufficient in itself, as was the objective of ensuring a level playing field. However, it was not convinced with regard to the perceived deterrent nature of provisional suspensions and the last ground, damage to the image of the sport, was considered the weakest as the horses would compete again

\footnotetext{
156 CAS 2017/A/5114 (n 13) para 43.

157 Ibid., para 45.

158 Ibid., para 58.

159 Ibid., para 64.
} 


\section{THE FÉDÉRATION EQUESTRE INTERNATIONALE SPEAKS FOR THE HORSE WHO HAS NO VOICE AND THE COURT OF ARBITRATION}

sometime in the future. ${ }^{160}$ The Panel distinguished the position of the horse with that of a human competitor as it stated: 'Horses, unlike humans, cannot themselves take care to avoid the ingestion of prohibited substances. The welfare and health argument has a proper and particular resonance in their case'. ${ }^{161}$

The Panel accepted that a one-size fits all approach as opposed to a bespoke solution was required given the range of equine sports and the different prohibited substances. ${ }^{162}$ The FEI, in its endeavours to protect horses, was of the view that the 'blanket' two-month suspension was both legitimate and proportionate. ${ }^{163}$ However, the Panel accepted that there could be more transparency with the rule, in that it could be in published form. ${ }^{164}$ It rejected the argument that the publicity of the rules was insufficient. Had there been a published rule, then its application would still not have adjusted their behaviour in the lead up to the adverse analytical finding and they were at all material times aware of their duty to ensure that the horses did not ingest a prohibited substance. The appellants were informed of the two-month equine suspension once the adverse analytical finding was communicated to them; thus it 'provided a target against which they could direct their forensic fire'. ${ }^{165}$ In any case, the FEI had passed a resolution in 2012 providing for the two-month suspension of the horse, which was evidenced by the minutes of a FEI Executive Board meeting dated 5-6 May 2012. ${ }^{166}$ The Panel referred to the FEI Bureau as the official body of the FEI, which according to the FEI Statutes is 'responsible for the general direction of the FEI and for all relevant matters not consigned to the General Assembly'. ${ }^{167}$ Article 20.1 of the FEI Statutes provides that the FEI Board's (formerly Bureau) role is ' $[t]$ o approve the Sport Rules (a) that

\footnotetext{
160 Ibid., para 65.

161 Ibid., para 68.

162 Ibid., para 69. At para 88 the Panel opined that 'any such potential unfairness is a price properly to be paid in the overall interests of equine sport'.

163 Ibid.

164 Ibid., para 71.

165 Ibid.

166 Ibid.

167 Ibid., para 72. The FEI Bureau was renamed the FEI Board (Chapter IV of the FEI Statutes, $24^{\text {th }}$ Edition, effective 20 November 2018) <https://inside.fei.org/fei/about-fei/feiboard> accessed 8 April 2019. The Board convenes two in-person Board meetings per year. The main decisions of the FEI Board from 18 to 19 June 2018 may be accessed here: <https://inside.fei.org/system/files/Main\%20decisions\%20Bureau\%20June\%202018_ FINAL_0.pdf $>$ accessed 8 April 2019. The FEI General Assembly's role is to act 'as a platform for discussions and voting on the major decisions of the FEI and the governance of the sport. It is held in a different location every year', FEI, 'FEI General Assembly' $<$ https://inside.fei.org/fei/about-fei/fei-general-assembly> accessed 8 April 2019.
} 
cannot await the next General Assembly.' ${ }^{168}$ Article 9.1 of the FEI Statutes states that the 'General Assembly of the National Federations is the supreme authority of the FEI' ${ }^{169}$ Article 10 lists the powers of the General Assembly, which includes the approval of the FEI Rules and Regulations. ${ }^{170}$ In referring to the "constitutional context', the Panel found that the Minutes of the FEI Executive Board dated 5-6 March 2012 explicitly stated that the FEI Tribunal had passed a resolution at its own meeting in 2012 that provided for the two-month equine provisional suspension. ${ }^{171}$ The rule was also referred to in the Meeting Minutes of the FEI Tribunal annual meeting, which took place on 13 February 2016. ${ }^{172}$ The minutes, as cited by the Panel, stated that the two-month provisional equine suspension was introduced on the grounds of equine welfare and to maintain a level playing field and that ' $[\mathrm{t}]$ he FEI Tribunal decision has been applied consistently since 2012'. ${ }^{173}$

The Panel gave cognisance to the fact that the two-month suspension is not absolute as Article 7.4.4 (i), (ii) and (iii) provide for the lifting of the suspension to the comfortable satisfaction of the FEI Tribunal. ${ }^{174}$ In reference to (i), the Panel noted that this did not apply as the appellants had not challenged the adverse analytical finding. In relation to (ii), the Panel noted that the lifting of suspensions refers to the PR, and not the horse. The Panel recommended that this section be revisited in order to prevent further argument especially considering that athletes have their own doping rules, the WADA rules. With regard to (iii), there were no exceptional circumstances, a provision that must be construed narrowly.

The Panel was not satisfied that the substance, although no longer in the horses' systems, did not mean that there were no residual effects. ${ }^{175}$ The Panel could not fault the testing methods used in laboratory. ${ }^{176}$ While the CAS dismissed the dressage riders' appeal, it decided that the results achieved would stand.

The decision was welcomed by the FEI, as its Secretary General Sabrina Ibáñez stated:

We are delighted to have received such a clear endorsement of the FEI's policy on equine provisional suspensions from the Court of Arbitration for Sport ...

\footnotetext{
168 FEI Statutes (n 168).

169 Ibid.

170 Ibid.

171 CAS 2017/A/5114 (n 13) para 73.

172 Ibid., 74.

173 Ibid., 75.

174 Ibid., paras 80-83.

175 Ibid., para 91.

176 Ibid., para 93.
} 
Horse welfare is always top of the agenda for the FEI and the mandatory two-month provisional suspension of horses in Banned Substance cases is an important measure to ensure that the welfare of our equine athletes is not compromised. $)^{177}$

\section{FEI Tribunal Final Decisions}

Blythe and Lyle's appeals were partially upheld by the CAS as the provisional suspensions imposed on the two horses, Horizon and Don Principe imposed by the FEI Tribunal were terminated, however, the FEI's policy of imposing a two-month suspension was declared valid. The matter was referred back to the FEI Tribunal. ${ }^{178}$ The FEI Tribunal issued two Final Decisions in December 2018, one in relation to Blythe and the other in relation to Lyle. ${ }^{179}$ The FEI Tribunal accepted that the athletes bore no significant fault or negligence. The athletes and the FEI reached an agreement on 12 November 2018. Under the terms of the agreement, the athletes accepted that the presence of a banned substance was a breach of Article 2.1 of the EAD Rules. ${ }^{180}$ The period of ineligibility was three months, beginning on 5 April 2017. As the horses were banned for one-month and not the standard two-months, the results for both the equine and human athlete from 5 April 2017 to 4 July 2017 were retrospectively disqualified. ${ }^{181}$ The PRs were each fined 3,000 Swiss francs and ordered to pay costs for the testing of Sample B. The agreement provided for appeal to the CAS; however, it would seem that neither Lyle nor Blythe appealed the FEI Tribunal's Final Decisions. ${ }^{182}$ The FEI Tribunal referred to paragraph 89 of the CAS decision where the Panel stated that it:

cannot assume, as was contended, that the Appellants were faultless in respect of such ingestion. In any event, that is a matter which will fall to be decided at the future hearing on the merits of this dispute, which will no doubt consider all the circumstances including the notorious fact that warnings about the possible contamination of supplements are well publicised. ${ }^{183}$

\footnotetext{
177 Press Release (n 143).

178 Decision of the FEI Tribunal in Blythe (n 39) and Decision of the FEI Tribunal in Lyle (n 39).

179 Ibid.

180 Ibid., 5.2 (1).

181 Ibid., 5.2 (4).

182 Ibid., 8.7 (2). The riders had 21 days to appeal the FEI Tribunal decision.

183 Ibid., 5.4 .
} 
The FEI Tribunal ratified the agreement between the FEI and Lyle and the FEI and Blythe. Thus, this brought to an end the protracted dispute between the two dressage riders and the FEI. The decision has wider implications as the CAS deemed the two-month provisional suspension to be valid and in accordance with the rules and regulations of the FEI.

\section{CONCLUSION}

The strict liability principle underpins the FEI's commitment to ensuring fairness in competition and equine welfare. This is augmented by the two-month provisional equine suspensions. The strict liability principle, while deemed 'unconscionable' and a breach of fundamental rights by academic commentators and riders alike, is here to stay. The horse is unable to verbalise and depends on the human agents to protect and safeguard it. The strict liability standard ensures that the rules surrounding prohibited substances and controlled medications are taken seriously. A departure from the strict liability standard could render the EADCMRs ineffective or inoperable. The PR is in a guardianship position and it is their responsibility to ensure that enquiries are made as to the ingredients and properties of substances. While the non-autonomous position of the horse has been used a reason for a reversal of burdens, it is submitted that this makes the horse all the more vulnerable and in need of greater protection.

The FEI recognises that there can be an innocent ingestion of a prohibited substance through contamination. In these cases, a more relaxed and flexible approach has been embraced by the FEI. A move away from strict liability in such instances and the adoption of a scale of offences or a reversal of burdens would signal that the FEI is aware of the current discourse and would reserve the strict liability standard for more serious infringements of the EADCMRs.

The FEI stance on doping is commendable as it puts the welfare of the equine athlete at the forefront. However, the EADCMRs are submerged in verboseness and legalese. They are 80 pages in length. At times, the Regulations are confusing especially as there are situations where the burden of proof is reversed and the balance of probabilities is used instead of the higher standard of 'to the comfortable satisfaction' of the FEI Tribunal. The EADs are a replication of the WADA rules, which were drafted with human athletes in mind. They are not fit for purpose. The Regulations need to be revised to reflect that the subject of the rules is an equine athlete, a sentient being and not a piece of equipment. The case of Blythe and Lyle demonstrates that the Regulations need to clearer and more concise. If the EADCMRs were redrafted with the horse in mind, it would reflect a more consistent approach of the FEI, which on the one-hand recognises the equine athlete in some situations, yet on the other hand, the Regulations do not refer to the equine athlete. 
Human athletes and racehorses are subject to out-of-competition testing, whereas the FEI carries out in-competition testing only. An overhaul of the Regulations that recognises the specific needs of the equine athlete and the introduction of out-of-competition testing for banned substances would give more credence to the Regulations.

The CAS decision has clarified the FEI's policy of imposing a two-month provisional suspension on equine athletes. It is a well-thought out decision that has as its core the welfare and health of horses. While the interim decision to provisionally lift the suspensions seemed to undermine the objectives of the FEI, the Panel took a very serious view of the impact of banned and other substances on the wellbeing of the horse. It is a much welcome decision as it solidifies the FEI policy and it is hoped that this will ensure that it is immune from further challenge. The 2019 Regulations do not include an explanation of the two-month provisional suspension. It is disappointing that the CAS's recommendation that the provision be more transparent and in published form was not taken on board in the drafting of the 2019 Regulations. The Regulations were revised prior to the FEI Tribunal Final Decisions; it may be that the next major revision of the Regulations will include a description of the two-month equine provisional suspension. 